
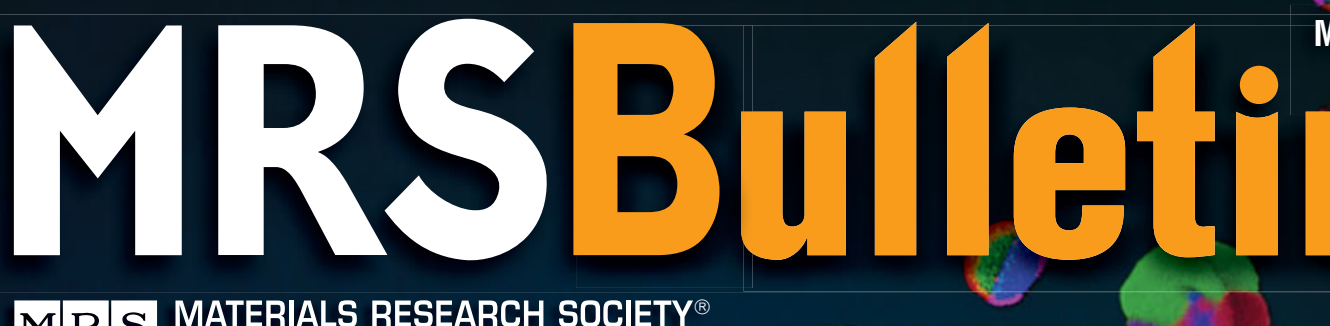

March 2014 Vol. 39 No. 3

www.mrs.org/bulletin

\begin{tabular}{l|l|l}
$M$ & $R$ & $S$ \\
Advancing materials. Improving the quality of life.
\end{tabular}<smiles>[18OH]</smiles>

$\ominus$

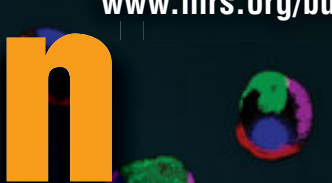

\title{
Organic nanoparticles
}

\section{for drug delivery} and imaging

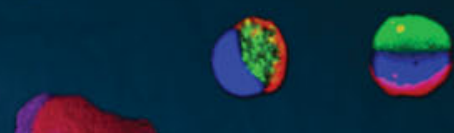




\section{CUSTOMIZED PRODUCTION ION IMPLANTERS}

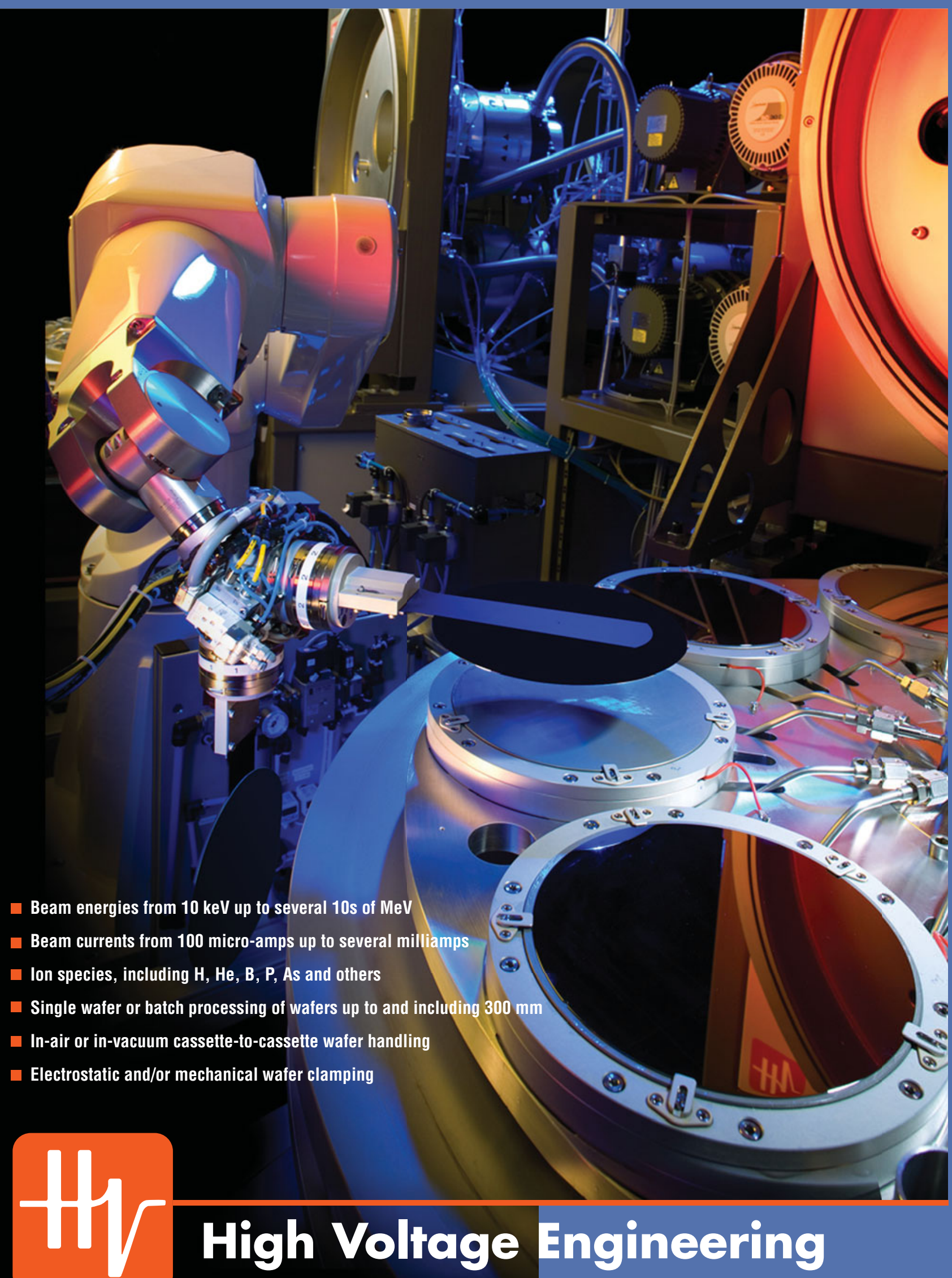

High Voltage Engineering Europa B.V.

P.O. Box 99, 3800 AB Amersfoort, The Netherlands

Tel: $31334619741 \cdot$ info@highvolteng.com

www.highvolteng.com 


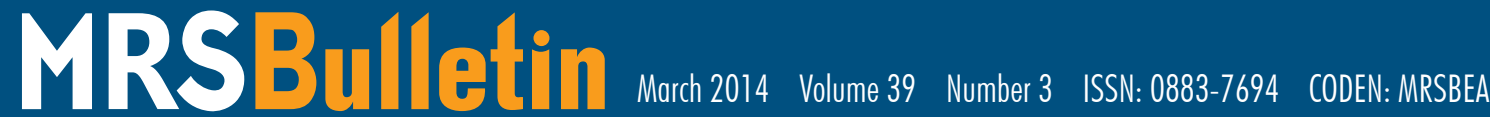
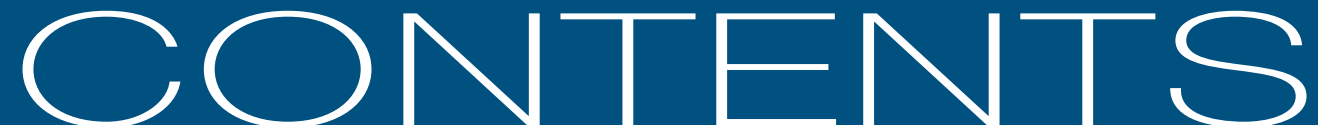

\section{ORGANIC NANOPARTICLES FOR DRUG DELIVERY AND IMAGING}

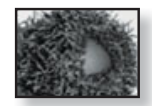

219 Organic nanoparticles for drug delivery and imaging

Samir Mitragotri and Patrick Stayton, Guest Editors

224 Meet Our Authors

227 Understanding nano-bio interactions to improve nanocarriers for drug delivery Ryan M. Pearson, Hao-jui Hsu, Jason Bugno, and Seungpyo Hong

239 Theranostic applications of organic nanoparticles for cancer treatment Ji Young Yhee, Sohee Son, Namho Kim, Kuiwon Choi, and Ick Chan Kwon

251 Recent progress with multicompartmental nanoparticles

Sahar Rahmani and Joerg Lahann

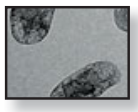

259 Clinical translational challenges

in nanomedicine

Shiladitya Sengupta

\section{Energy Quarterly}

213 Editorial

Maintaining hope for sustainable energy

Sossina M. Haile

214 Regional Initiative

Israel makes an ambitious move

on alternative fuels

Prachi Patel

FEATURE EDITOR: Anat Bonshtien

216 Interview

Superconductivity to cosmology: K. Alexander Müller explores mysteries in energy

Interviewed by Anke Weidenkaff

www.mrs.org/energy-quarterly

\section{DEPARTMENTS}

\section{OPINION}

198 Letter from the President

The MRS mission and industry

Tia Benson Tolle and Shenda Baker

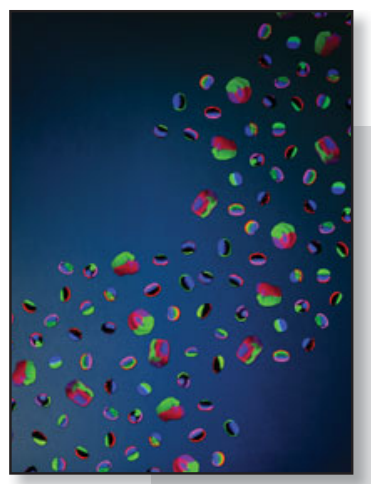

\section{ON THE COVER}

Organic nanoparticles for drug delivery and imaging. A number of organic nanoparticles have been developed to encapsulate and deliver therapeutic and imaging agents. The articles in this issue of MRS Bulletin highlight applications of organic nanoparticles for therapeutic delivery and imaging, and focus on recent advances in this field. The cover shows one-, two-, and three-patch surfaces of multicompartmental particles that, because of their unique characteristics, can be selectively surface-modified based on the incorporated functional polymers. Different fluorescent labeled molecules were used on the surface and within each compartment of the particles shown, which were then imaged with a confocal microscope. Such particles can be used for drug delivery, tissue engineering, self-assembly, and novel gel formation. Image courtesy of Sahar Rahmani. See the technical theme that begins on page 219 . 


\section{- NEWS \& ANALYSIS}

\section{Materials News}

- Molecule transforms metal-organic framework to become conducting

Meg Marquardt

- Inexpensive organic flow battery is metal-free

- Contact lens elutes glaucoma medication sustainably for one month

Jen Gordon

- Skin pigment enables edible battery for biodegradable devices

Prachi Patel

- Quantitative STEM technique extracts 3D atom stacking information from $2 \mathrm{D}$ image Dirk Wouters

\section{Science Policy}

- US Congress proposes alternative to COMPETES Act Jennifer A. Nekuda Malik

- European Commission launches pilot to open publicly funded research data

\section{FEATURES}

\section{Posterminaries \\ Famous last words \\ Tim Palucka}

\section{SOCIETY NEWS}

- Materials Research Society celebrates 40th anniversary with more cutting-edge research at the 2013 MRS Fall Meeting

- Remembering the legacy of Fred Kavli Lori A. Wilson

- John J. Tracy of Boeing to give plenary address at 2014 MRS Spring Meeting

- MRS expands materials publications landscape Birgit Schwenzer

- Materials Research Society 2013 year-end review

\section{CAREER CENTRAL}

\section{ADVERTISERS IN THIS ISSUE}

Aldrich Materials Science American Elements

Annual Reviews

* Asylum Research

an Oxford Instruments Company

* Chemistry of Materials

* CRAIC Technologies, Inc.

* CRC Press

High Voltage Engineering Hindawi Publishing Corporation ......... Inside back cove

* HORIBA Scientific

* International Centre for Diffraction Data (ICDD). .211

* JEOL USA, Inc.

* Kurt J. Lesker Company

* Lake Shore Cryotronics, Inc.

Lehigh Microscopy School

* National Electrostatics Corp.

* Rigaku Corporation

Wiley

J.A. Woollam Company, Inc.

XENON Corporation

Page No.

193 Outside back cover

\section{ver} 250 197 226 218 264 223 237 203 210

* Please visit us at the exhibit, April 22-23, during the 2014 Materials Research Society Spring Meeting in San Francisco. 


\section{About the Materials Research Society}

The Materials Research Society (MRS), a not-for-profit scientific association founded in 1973 and headquartered in Warrendale, Pennsylvania, USA, promotes interdisciplinary materials research. Today, MRS is a growing, vibrant, member-driven organization of over 16,000 materials researchers spanning over 80 countries, from academia, industry, and government, and a recognized leader in the advancement of interdisciplinary materials research.

The Society's interdisciplinary approach differs from that of single-discipline professional societies because it promotes information exchange across many scientific and technical fields touching materials development. MRS conducts three major international annual meetings encompassing approximately 125 topical symposia, and also sponsors numerous single-topic scientific meetings. The Society recognizes professional and technical excellence and fosters technical interaction through University Chapters. In the international arena, MRS implements bilateral projects with partner organizations to benefit the worldwide materials community. The Materials Research Society Foundation helps the Society advance its mission by supporting various projects and initiatives.

MRS publishes MRS Bulletin, MRS Communications, the MRS Online Proceedings Library, Journal of Materials Research, MRS Energy \& Sustainability, and books and textbooks with its publishing partner, Cambridge University Press.

\section{MRS BOARD OF DIRECTORS}

President Tia Benson Tolle, The Boeing Company, USA Immediate Past President Orlando Auciello, University of Texas at Dallas, USA

Vice President and President-Elect Oliver Kraft, Karlsruhe Institute of Technology, Germany

Secretary Sean J. Hearne, Sandia National Laboratories, USA

Treasurer Michael R. Fitzsimmons, Los Alamos National Laboratory, USA

Executive Director Todd M. Osman, Materials Research Society, USA

Shenda M. Baker, Synedgen, Inc./Harvey Mudd College, USA

Alexandra Boltasseva, Purdue University, USA

C. Jeffrey Brinker, Sandia National Laboratories and University of New Mexico, USA

David Cahen, Weizmann Institute of Science, Israel

Steve Eglash, Stanford University, USA

Chang-Beom Eom, University of Wisconsin-Madison, USA

Susan Ermer, Lockheed Martin Advanced Technology Center, USA

Eric Garfunkel, Rutgers University, USA

Sossina M. Haile, California Institute of Technology, USA

Andrea M. Hodge, University of Southern California, USA

Hideo Hosono, Tokyo Institute of Technology, Japan

Fiona C. Meldrum, University of Leeds, UK

Kornelius Nielsch, University of Hamburg, Germany

Eric A. Stach, Brookhaven National Laboratory, USA

Stephen Streiffer, Argonne National Laboratory, USA

Loucas Tsakalakos, General Electric-Global Research Center, USA

\section{MRS OPERATING COMMITTEE CHAIRS}

Academic Affairs Bruce Clemens, Stanford University, USA

Awards C. Barry Carter, University of Connecticut, USA

Government Affairs Nabil Bassim, US Naval Research Laboratory, USA

Meetings Committee David S. Ginley, National Renewable Energy Laboratory, USA

Member Engagement Yves Chabal, The University of Texas at Dallas, USA Public Outreach Aditi Risbud, University of Utah in Salt Lake City, USA

Publications Susan Trolier-McKinstry (Acting Chair), The Pennsylvania State University, USA

MRS OFFICE OF PUBLIC AFFAIRS

Ron Kelley 499 South Capitol St. SW, Suite 600, Washington, DC 20003
EDITORIAL OFFICE 506 Keystone Drive, Warrendale, PA 15086-7573 USA Bulletin@mrs.org tel 724.779.2747 fax 724.779.8313 www.mrs.org
Editor

Gopal R. Rao, rao@mrs.org

Managing Editor

Judy Meiksin, meiksin@mrs.org

Technical Editor

Lori A. Wilson, Iwilson@mrs.org

Editorial Assistants

Michelle S. Raley, raley@mrs.org

Mary Wilmoth

Associate Technical Editor

Carol Tseng

Production/Design

Andrea Pekelnicky, Rebecca Yokum,

and TNQ

Production Editor

Catherine Paduani

Science News Editor

Tim Palucka

Principal Development Editor

Elizabeth L. Fleischer

Director of Communications

Eileen Kiley Novak
Guest Editors

Samir Mitragotri and Patrick Stayton

Special Consultant

Avery Meiksin

\section{Energy Quarterly}

Anke Weidenkaff (Chair)

Anshu Bharadwaj, David Cahen,

Russell R. Chianelli, George Crabtree,

Sabrina Sartori, M. Stanley Whittingham, and Steve M. Yalisove

Advertising/Sponsorship

Mary E. Kaufold, kaufold@mrs.org

Donna L. Watterson, watterson@mrs.org

Member Subscriptions

Michelle Judt, judt@mrs.org

Non-Member Subscriptions

subscriptions_newyork@cambridge.org

\section{EDITORIAL BOARD}

Paul S. Drzaic (Chair), Apple, Inc., USA

V.S. Arunachalam, Center for Study of Science, Technology \& Policy, India

Marie-Isabelle Baraton, University of Limoges, France

Hanns-Ulrich Habermeier, Max Planck Institute for Solid State Research, Germany

Igor Lubomirsky, Weizmann Institute, Israel

Fiona C. Meldrum, University of Leeds, UK

Amit Misra, Los Alamos National Laboratory, USA

Steven C. Moss, Aerospace Corporation, USA

Julie A. Nucci, Cornell University, USA

Linda J. Olafsen, Baylor University, USA

James W. Stasiak, Hewlett-Packard Co., USA

Carol Trager-Cowan, University of Strathclyde, UK

Anke Weidenkaff, University of Stuttgart, Germany

Eric Werwa, Washington, DC, USA

Steve M. Yalisove, University of Michigan, USA

\section{VOLUME ORGANIZERS}

2015 Ying-Hao (Eddie) Chu, National Chiao Tung University, Taiwan Kalpana S. Katti, North Dakota State University, USA

Tommie W. Kelley, 3M, USA

Jud Ready, Georgia Institute of Technology, USA

2014 Deborah E. Leckband, University of Illinois at Urbana-Champaign, USA Yuri Suzuki, Stanford University, USA

Enrico Traversa, King Abdullah University of Science and Technology, Saudi Arabia Yonhua Tzeng, National Cheng Kung University, Taiwan

2013 Mark T. Lusk, Colorado School of Mines, USA Eva Olsson, Chalmers University of Technology, Sweden Birgit Schwenzer, Pacific Northwest National Laboratory, USA James W. Stasiak, Hewlett-Packard Co., USA Materials Research Society. Permission required to reproduce content. Periodical postage paid at New York, NY, and at additional mailing offices. POSTMASTER: Send address changes to MRS Bulletin in care of the Journals Department, Cambridge University Press, 100 Brook Hill Drive, West Nyack, NY 10994-2113, USA. Printed in the U.S.A.

Membership in MRS is $\$ 115$ annually for regular members, $\$ 30$ for students. Dues include an allocation of $\$ 29$ ( $\$ 17$ for students) to a subscription to MRS Bulletin. Individual member subscriptions are for personal use only. Non-member subscription rates are $\$ 439$ for one calendar year (12 issues) within North America and $\$ 527$ elsewhere. Requests from subscribers for missing journal issues will be honored without charge only if received within six months of the issue's actual date of publication.

(5) base, Research Alert ${ }^{\oplus}$ Science Citation Index ${ }^{\circledast}$, and the Materials Science Citation IndexTM. Back volumes of MRS Bulletin are available on microfiche through University Microfilms Inc. 300 North Zeeb Road, Ann Arbor, MI 48106, USA. 


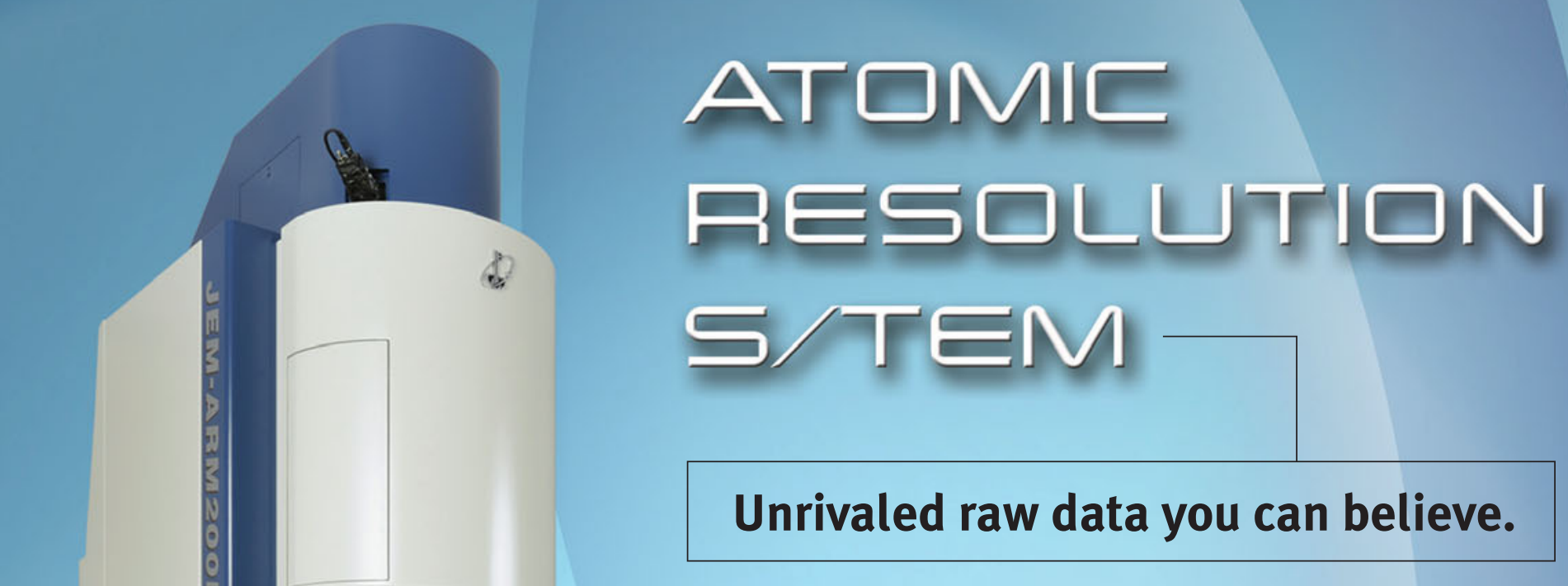

Atom-by-atom sub-angstrom imaging resolution, atom-to-atom chemical mapping, aberration correction, 2 and 3-D reconstruction, and optional Cold FEG. What can we help you achieve?

Dr. John Bradley

University of Hawaii

Commercial NCM Cathode Material for

Li-Ion Batteries. Atomic EDS map. Overlay

shows O (red), $\mathrm{Ni}$ (blue), $\mathrm{Mn}$ (green).

$0.5 \mathrm{~nm}$

Dr. Miguel Jose Yacaman

University of Texas, San Antonio

Sample provided by Tour Lab, Rice University

Chiral Nanotube with parameters $n=10$ and $m=4$ (simulated and experimental).

\begin{tabular}{l|l} 
www.jeolusa.com \\
salesinfo@jeol.com \\
$978-535-5900$
\end{tabular}

$0.5 \mathrm{~nm}$

\section{Solutions for Innovation}

Dr. Moon Kim

University of Texas, Dallas

STEM HAADF image of transferred $\mathrm{MoS}_{2}$, showing Mo and $S$ atom positions and their $2 \mathrm{H}$ stacking sequence.

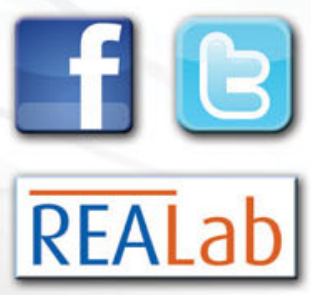

$0.5 \mathrm{~nm}$ 